\title{
Exergy Analysis on Thermal Power Plant PT. Makassar Tene Using Cycle-Tempo 5
}

\author{
La Ode Musa ${ }^{1^{*}}$, Apollo ${ }^{2}$, Aini Syahrunnisa ${ }^{3}$ dan Muhammad Yusuf ${ }^{4}$ \\ 1,2,3,4 Jurusan Teknik Mesin, Politeknik Negeri Ujung Pandang, Makassar 90245, Indonesia \\ *laodemus_pnup@yahoo.com
}

\begin{abstract}
Analyzing exergy on the power plant generating system specially at PLTU, efficient utilization of energy resources can be obtained particularly since it leads efforts to reduce energy waste that already exists. The purposes of this research are to get the Thermal Power Plant system modeling of PT. Makassar Tene, to get the value of modeled exergy power plant system, to get exergy losses, to get the amount exergy efficiency and to get the cost of exergy losses. The research method was firstly, designing the Power Plant generating systems PT. Makassar Tene using Cycle-Tempo 5 as thermodynamic analysis tool. Results of calculations were then used to calculate the exergy profile. Exergy values analyzed on a system modeled Power Plant consists of turbine components, condensers and pump. Boilers are not included in the analysis because of the input device is not contained and the mass flow rate of the boiler occurs steady state in which the state of the same process with the state of the environment so that there is no exergy difference that can be utilized. The highest exergy losses based on the modelling was on the turbine components that was $10201.50 \mathrm{~kW}$. This was due to the change in the vapor phase into the liquid phase contained in the component before and after leaving the turbine components. While the lowest exergy losses was on the pump component, that was $437.18 \mathrm{~kW}$. The higher the efficiency value of a component, the better its performance is. The highest efficiency value of exergy that was $51.43 \%$ contained on the turbine components. While the lowest efficiency value of exergy was $0 \%$.
\end{abstract}

Keywords: Exergy, Cycle-Tempo, steady state, losses

\begin{abstract}
Abstrak: Analisis eksergi pada sistem pembangkit listrik khususnya di PLTU, pemanfaatan sumber daya energi yang efisien dapat diperoleh terutama karena hal itu mengarah pada upaya mengurangi limbah energi yang sudah ada. Tujuan dari penelitian ini adalah untuk mendapatkan pemodelan sistem Pembangkit Listrik Thermal PT. Makassar Tene, untuk mendapatkan nilai pemodelan eksergi sistem pembangkit tenaga listrik, untuk mendapatkan rugi-rugi eksergi, untuk mendapatkan efisiensi eksergi dan untuk mendapatkan biaya dari kerugian eksergi. Metode penelitian pertama-tama, merancang sistem pembangkit Listrik PT. Makassar Tene menggunakan Cycle-Tempo 5 sebagai alat analisis termodinamika. Hasil perhitungan kemudian digunakan untuk menghitung profil eksergi. Nilai eksergi yang dianalisis pada sistem yang dimodelkan Pembangkit terdiri dari komponen turbin, kondensor dan pompa. Boiler tidak dimasukkan dalam analisis karena perangkat input tidak terkandung dan laju aliran massa boiler terjadi keadaan tunak di mana keadaan proses yang sama dengan keadaan lingkungan sehingga tidak ada perbedaan exergi yang dapat dimanfaatkan. Kehilangan eksergi tertinggi berdasarkan pemodelan adalah pada komponen turbin yang 10201,50 kW. Hal ini disebabkan oleh perubahan fase uap menjadi fase cair yang terkandung dalam komponen sebelum dan sesudah meninggalkan komponen turbin. Sementara kerugian eksergi terendah ada pada komponen pompa, yaitu 437,18 kW. Semakin tinggi nilai efisiensi suatu komponen, semakin baik kinerjanya. Nilai efisiensi eksergi tertinggi yaitu $51,43 \%$ terkandung pada komponen turbin. Sedangkan nilai efisiensi eksergi terendah adalah $0 \%$.
\end{abstract}

Kata kunci : Eksergi, Cycle-Tempo, steady state, rugi-ugi

\section{PENDAHULUAN}

Dalam suatu kegiatan proses bisnis pembangkitan energi listrik tentunya energi yang dihasilkan tidak akan mutlak mencapai $100 \%$ dari energi yang diproduksi. Oleh karena itu setiap pembangkit memiliki tingkat efisiensi yang berbeda tergantung dari metode operasi dan pemeliharaan setiap pembangkit.

Efisiensi merupakan indikator dan aspek yang paling penting diperhatikan dalam mengukur kinerja keseluruhan dari sistem pembangkitan energi. Efisiensi dalam suatu pembangkitan energi listrik menyangkut pengelolaan hubungan input dan output tentang bagaimana cara kita mengalokasikan faktor-faktor produksi yang tersedia 
Secara optimal untuk dapat menghasilkan output yang maksimal. Tingkat efisiensi dapat diukur jika dengan jumlah input tertentu dapat menghasilkan jumlah output lebih banyak. efisiensi berarti bertindak dengan cara yang dapat meminimalisir kerugian atau pemborosan sumber daya dalam melaksanakan atau menghasilkan sesuatu.

Energi terdiri dari eksergi dan anergi. Eksergi adalah besarnya energi yang dapat dimanfaatkan untuk menghasilkan kerja sedangkan anergi adalah energi yang tidak dapat dimanfaatkan dan yang di buang ke lingkungan.

Rugi-rugi energi adalah suatu kondisi atau keadaan dimana jumlah energi yang disalurkan tidak sama dengan jumlah energi yang diterima pada sisi keluaran. Terjadinya rugi-rugi energi ini dapat disebabkan oleh berbagai faktor seperti rugi-rugi mekanikal dan elektrikal dimana rugi-rugi mekanikal dapat berupa gesekan bantalan dan udara sedangkan rugi-rugi elektrikal terdiri atas rugirugi besi dan tembaga. Semua rugi-rugi akan mengakibatkan terjadinya panas yang harus dihilangkan melalui pendinginan.

Idealnya pada sistem PLTU, kita menghendaki agar energi kimia (input) dapat diubah seluruhnya menjadi energi listrik (output). Pada kenyataannya, hal ini tidak mungkin dapat dilaksanakan karena adanya berbagai kerugian (losses) yang terjadi hampir di setiap komponen PLTU. Akibat kerugiankerugian tersebut, maka energi listrik yang dihasilkan PLTU selalu lebih kecil dari energi kimia yang masuk ke sistem PLTU.

Salah satu metode alternatif yang bisa digunakan untuk mengetahui penggunaan energi adalah analisis eksergi. Analisis eksergi adalah merupakan piranti yang menarik untuk mengidentifikasi lokasi irreversibilitas atau kerugian eksergi dan tingkat ketidakefisienan dari sistem pembangkit daya. Analisis eksergi bukan hanya dapat menentukan besar, lokasi dan penyebab irreversibilitas pada sistem pembangkit melainkan juga mengetahui efisiensi komponen sistem pembangkit [1]. Dengan analisis eksergi, diharapkan tidak ada energi dan eksergi yang terbuang percuma ke lingkungan sesuai harapan PLTU khususnya PLTU PT. Makassar Tene.

Analisis eksergi telah banyak dilakukan pada berbagai pembangkit diantaranya adalah analisis eksergi pada pembangkit listrik tenaga uap yang dilakukan diantaranya adalah di PLTU Banten 3 yang berlokasi di Lontar merupakan PLTU dengan bahan bakar batubara yang memiliki kapasitas produksi sebesar 3 x 315 MW [2], juga dilakukan pada sistem HTR-10 siklus turbin uap yang berlokasi di Kawasan Puspiptek, Serpong [3]. Analisis eksergi yang lain dilakukan pada pembangkit listrik tenaga gas yang dilakukan di PLTGU PT. Indonesia Power UP Perak-Grati dan berfokus pada pada siklus turbin gas [4]. Analisis eksergi yang lain juga dilakukan pada pembangkit listrik tenaga gas uap yang dilakukan di PLTGU yang berlokasi di Teluk Lembu dengan kapasitas $30 \mathrm{MW}$ komponen utama yang dianalisis adalah combustion chamber [5]. Analisis eksergi juga dilakukan pada pembangkit listrik tenaga panas bumi yaitu pada PLTP Kamojang analisis dilakukan pada sumur KMJ-68 dengan kapasitas 3 MW [6].

Analisis eksergi dapat dilakukan dengan berbagai cara baik manual maupun menggunakan alat bantu yaitu diantaranya adalah dengan menggunakan Engineering Equation Solver (EES) Software [6], juga dilakukan dengan menggunakan program cycle tempo [3, 7].

PT. Makassar Tene adalah merupakan pabrik gula rafinasi pertama dan satu-satunya yang beroperasi di kawasan timur Indonesia yang mampu memproduksi sampai 1.800 Ton gula rafinasi per hari untuk memenuhi kebutuhan gula di kawasan timur Indonesia. PLTU di PT Makassar Tene berkapasitas 3 × 6 MW dengan kebutuhan rata-rata 4-4,5 MW per hari untuk satu pabrik dengan rincian pabrik membutuhkan pasokan daya sebesar 2-2,5 MW dan untuk pembangkitnya sendiri menggunakan daya sekitar 2 MW. Besarnya pasokan daya yang dibutuhkan pabrik tiap harinya mengharuskan industri gula ini menggunakan pembangkit sendiri untuk menghasilkan uap ekstraksi yang dapat digunakan untuk kebutuhan pabrik seperti memasak gula dan lain-lain. Oleh karena itu, 
dilakukan sebuah studi analisis eksergi pada sistem pembangkit tersebut. Selain itu, sejauh ini belum ada yang melakukan penelitian di lokasi tersebut dengan menggunakan cycle-tempo 5. Salah satu program yang dapat digunakan untuk menganalisis eksergi adalah program Cycle-Tempo 5. Program Cycle-Tempo 5 dapat digunakan untuk mendesain, menganalisis, mengoptimalkan dan memonitor sistem energi yang dirancang dan dioperasikan. Selain itu terdapat fitur lengkap untuk menganalisis biaya rugi-rugi eksergi untuk optimasi yang akurat sesuai sistem yang dirancang dan dioperasikan.

Cycle Tempo adalah program untuk pemodelan termodinamika dan optimasi sistem untuk produksi listrik, panas dan pendinginan. Program ini berisi sejumlah besar model untuk aparatus dan pipa yang dapat digunakan membangun model sistem sesuai keinginan.

Program Cycle Tempo terdiri dari dua komponen utama, yaitu Apparatuses dan Connections. Adapun jenis peralatan yang tersedia dalam cycle tempo dapat dilihat dari Tabel 1 .

Tabel 1. Ringkasan komponen pada cycle tempo

\begin{tabular}{|l|l|l|l|}
\hline Type & Default name & \multicolumn{1}{|c|}{ System equations } & \\
\hline I & Bailer & IM & \\
\hline 2. & Reheater & IM & \\
\hline 3 & Turbine & IM & \\
\hline 5 & Flash.Heater & $2 \mathrm{M}-\mathrm{IE}$ & \\
\hline & & & \\
\hline & & & \\
\hline & & & \\
\hline & & & \\
\hline
\end{tabular}




\begin{tabular}{|c|c|c|c|}
\hline Туре & Default name & Systam squations & Symbal \\
\hline 6,12 & Jeat Exchyr. & $\begin{array}{ll}2 \mathrm{M} & \text { (EEQCOD - 2; type 6) } \\
2 \mathrm{M}-[\mathrm{P} & \text { (EEDCOD - 1; type 12) }\end{array}$ & \\
\hline 7 & Deaenator & $I M-I E$ & \\
\hline 8 & Pump & $2 \mathrm{M}$ & \\
\hline 9.11 & Node & 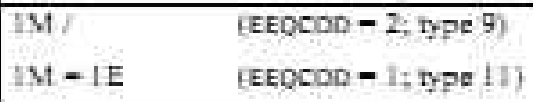 & \\
\hline 10 & Sink Sourre & $\begin{array}{l}\text { IM } \\
\text { (in cars of anly I pipe connested then } \\
\text { IM only if DELM, DELV or DELVN } \\
\text { a specified) }\end{array}$ & \\
\hline In & Heat Sink & $\begin{array}{l}\text { IM } \\
\text { (in case of anly I pipe connected then } \\
\text { iM aniy if DELM, DELV or DELVX } \\
\text { is specified) }\end{array}$ & \\
\hline in) & Stack & $\begin{array}{l}\text { IM } \\
\text { ronly if DELM, DELV or DELVN is } \\
\text { specified) }\end{array}$ & \\
\hline 13 & Combustor & 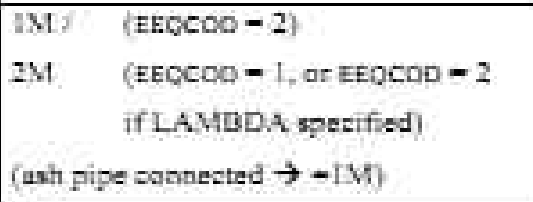 & \\
\hline I4 & Vaive & $2 M$ & \\
\hline 15 & Drum: & $1 M-1 E$ & \\
\hline
\end{tabular}




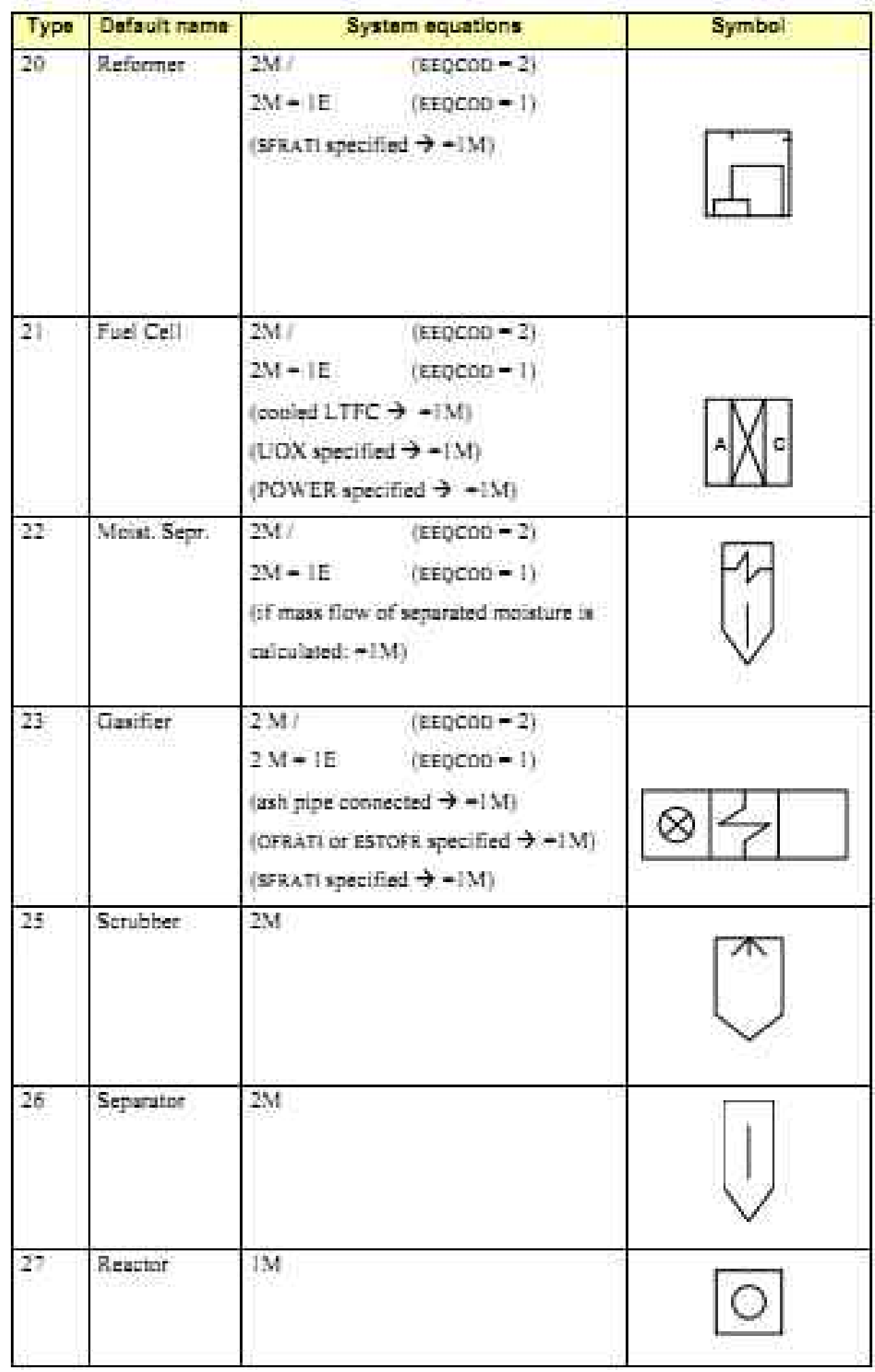




\begin{tabular}{|c|c|c|c|}
\hline Type & Default name & System equations & Symbol \\
\hline 28 & Saturator & $2 \mathrm{M}$ & \\
\hline 29 & Compressor & $1 \mathrm{M}$ & \\
\hline 30 & Gas turbine & $1 \mathrm{M}$ if a bottoming cycle is present & \\
\hline $\bar{G}$ & Generator & $\cdot$ & \\
\hline $\bar{M}$ & Electromotor & - & \\
\hline
\end{tabular}

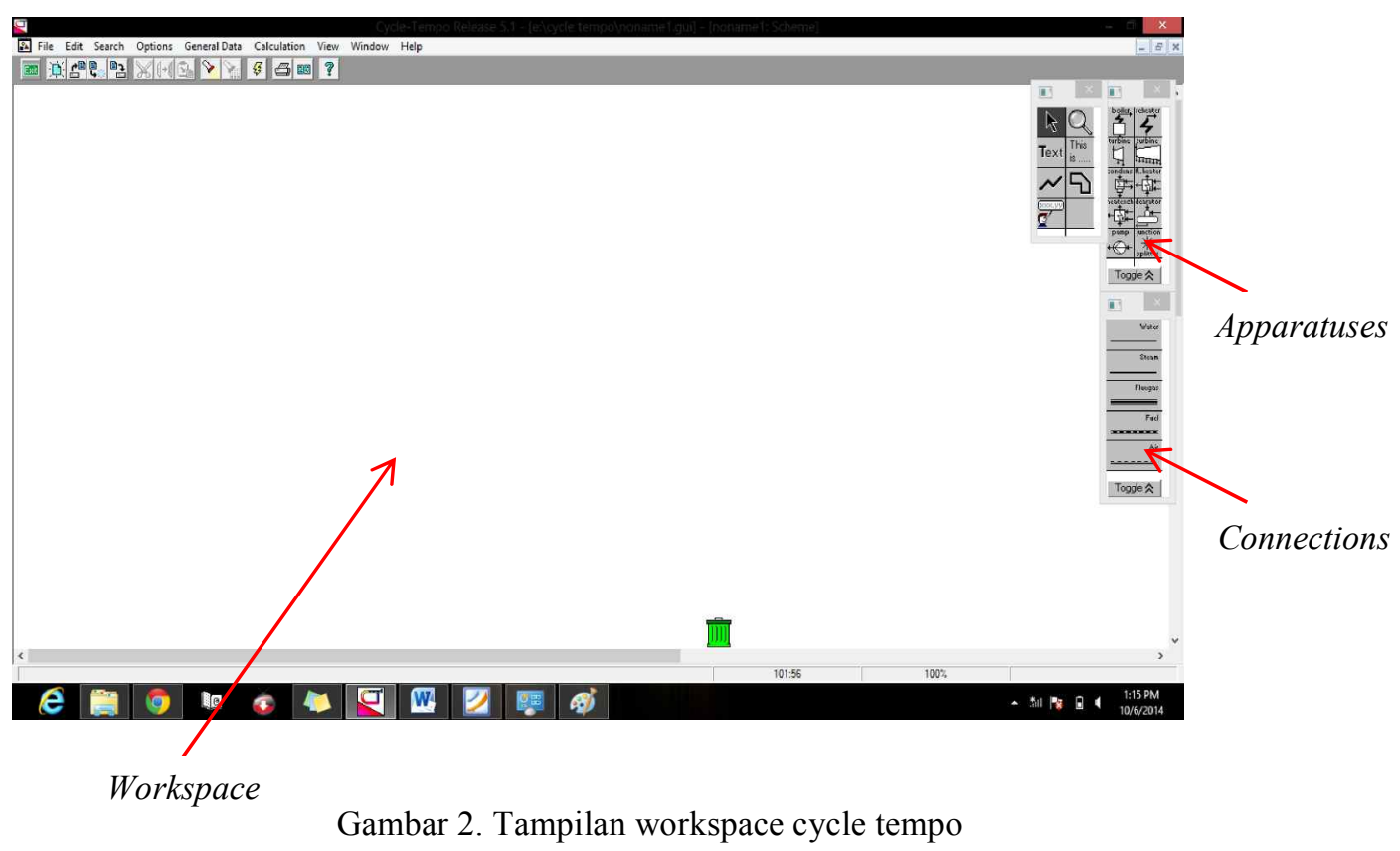




\section{METODE PENELITIAN}

Setelah mengumpulkan data dan parameter yang akan dipergunakan dalam simulasi serta membuat asumsi-asumsi yang diperlukan, kemudian dilakukan analisis dengan menggunakan software cycle tempo 5 sebagai piranti analisis termodinamika. Selanjutnya dari hasil cycle tempo, maka akan dianalisis profil eksergi seperti nilai eksergi, nilai eksergi yang hilang, efisiensi eksergi serta biaya rugi-rugi eksergi dengan perhitungan termoekonomi sesuai permodelan yang dibuat untuk menjawab tujuan penelitian tugas akhir ini.

\section{HASIL DAN PEMBAHASAN}

Sistem PLTU pada PT. Makassar Tene dimodelkan menggunakan perangkat lunak Cycle-Tempo 5 yang dikembangkan oleh TU Delft untuk melakukan pemodelan termodinamika dari sebuah sistem pengubah energi beserta simulasinya. Permodelan sistem PLTU PT. Makassar Tene terdiri dari pemodelan siklus uap. Siklus uap terdiri dari komponen boiler, turbin, kondenser, pompa kondenser, tangki air, pompa, deaerator, dan Boiler Feed Water Pump (BFWP). Bahan bakar dan udara pembakaran yang digunakan dalam pemodelan memiliki komposisi standar dari Cycle Tempo. LHV (Low Heating Value) batubara sesuai dengan data desain yaitu $4500 \mathrm{~kJ} / \mathrm{kg}$. Hasil pemodelan sistem PLTU ditunjukkan oleh Gambar 1.

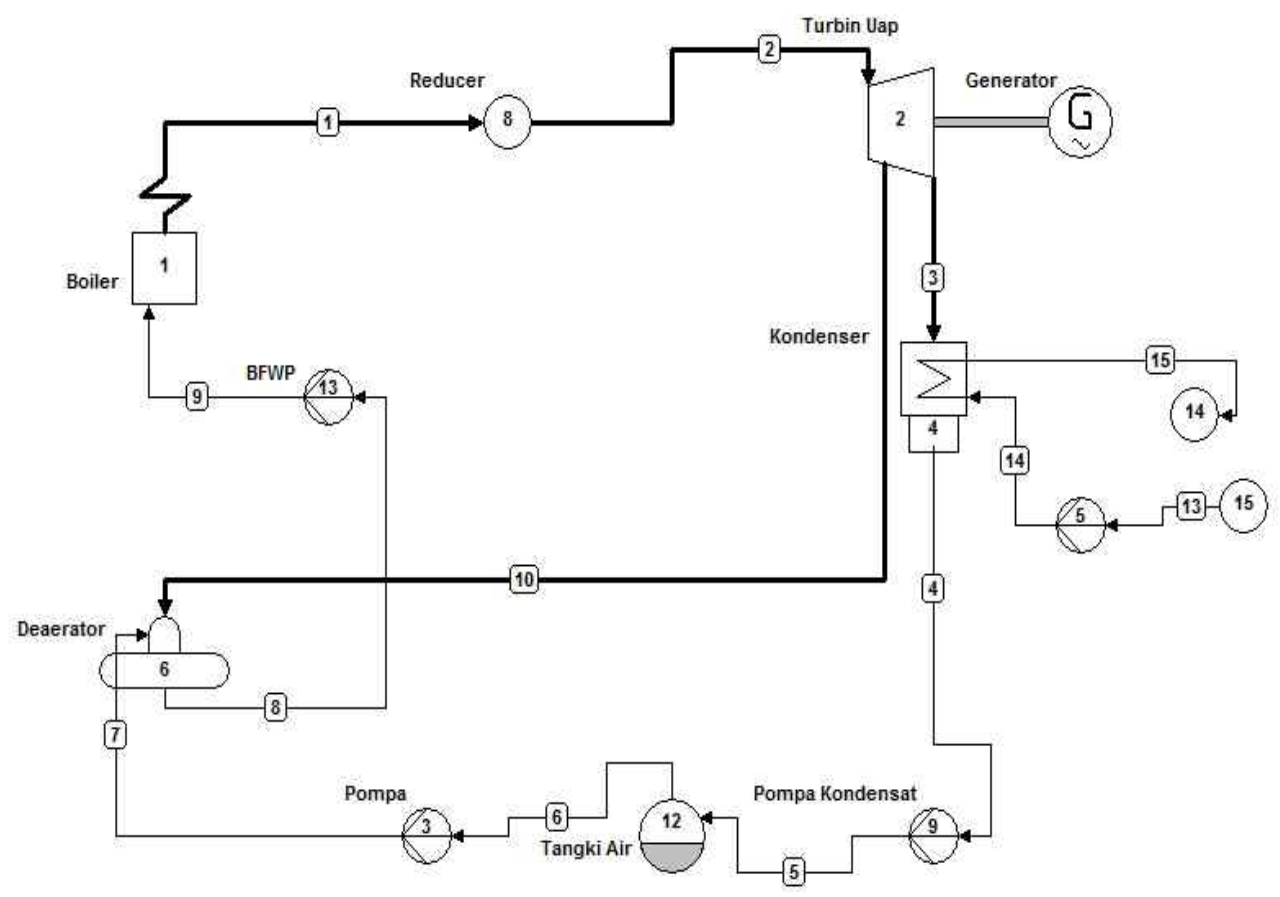

Gambar 3. Model Sistem PLTU

Model siklus uap menggunakan turbin back pressure. Jenis turbin ini dipilih karena turbin ini beroperasi pada tekanan uap keluar dari turbin di atas tekanan atmosfir sehingga masih dapat digunakan untuk keperluan lain, misalnya untuk pemanasan dan perebusan. Turbin back pressure dimodelkan secara langsung. Turbin back pressure pada data desain memiliki frekuensi putaran 50 $\mathrm{Hz}(3000 \mathrm{rpm})$. Model turbin back pressure menggunakan turbin tipe ke-6 yaitu tipe back pressure turbine (pressure controlled). Turbin ini menghasilkan daya sebesar $6 \mathrm{MW}$.

Simulasi model sistem PLTU pada Cycle-Tempo akan menghasilkan nilai parameter-parameter fluida kerja pada setiap komponen. Parameter-parameter tersebut meliputi laju aliran massa sistem, 
entalpi, entropi, eksergi dan energi. Gambar 4 merupakan diagram alur perhitungan oleh CycleTempo. Diagram menggambarkan proses perhitungan oleh Cycle-Tempo mulai dari pembacaan data sampai dengan perhitungan eksergi. Diagram alur tahapan yang dilakukan oleh Cycle-Tempo dalam mensimulasikan sebuah pemodelan dapat dilihat pada Gambar di bawah ini. Perhitungan exergy pada permodelan dengan Cycle-Tempo dilakukan dengan memasukkan parameter input yang dibutuhkan sesuai keadaaan PLTU yang ditinjau untuk melakukan proses perhitungan dan iterasi software. Pertama-tama harus dimasukkan terlebih dahulu environment defenition yaitu kondisi termodinamik lingkungan, temperatur dan tekanan yang akan dimasukkan sebagai referensi perhitungan exergy.

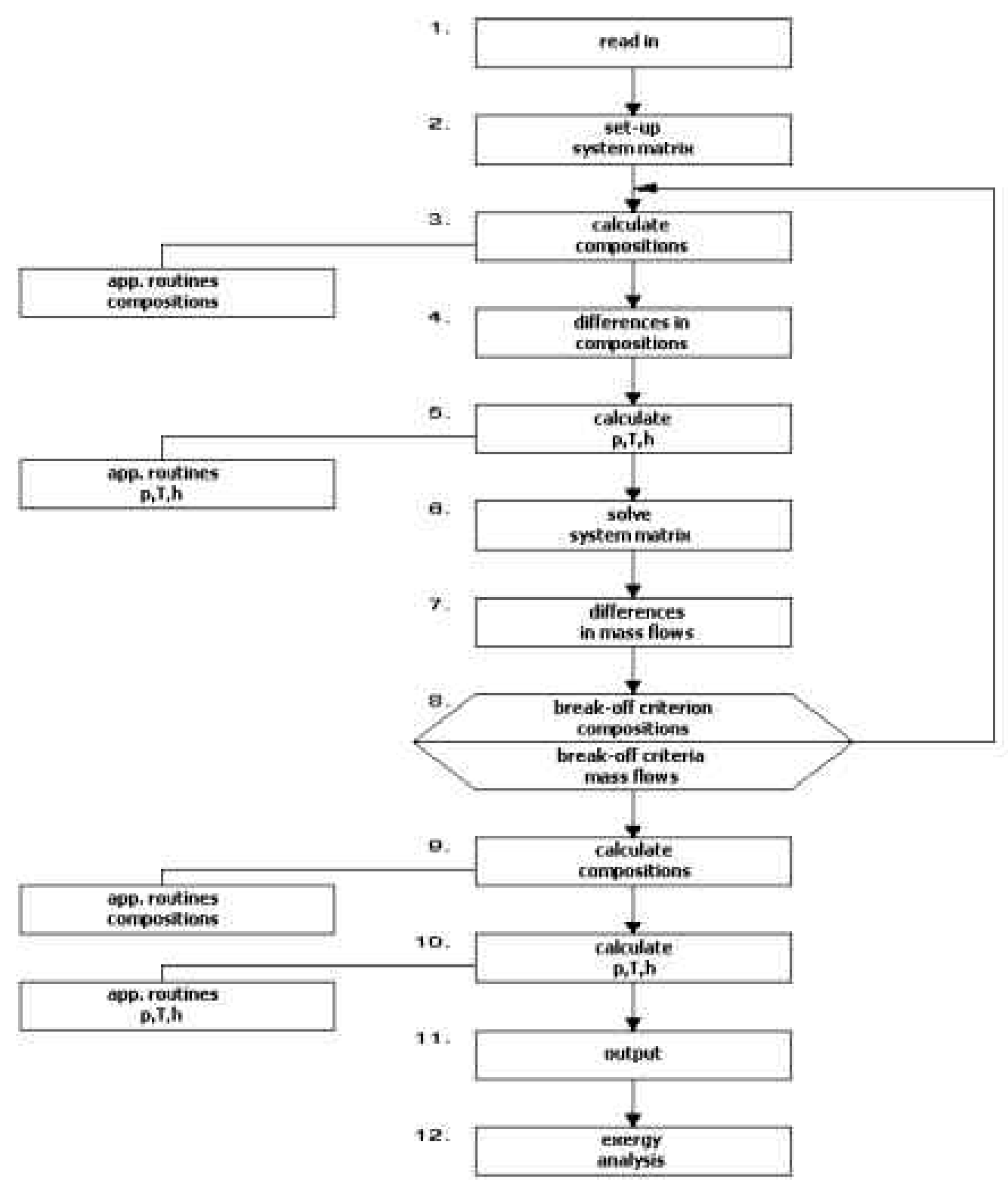

Gambar 4. Diagram Alur Perhitungan Cycle-Tempo

\section{Keterangan:}

a. Reading In, pembacaan terhadap model yang telah dibuat yang mencakup jumlah komponen, jumlah pipa, fluida kerja pada setiap pipa, dan sebagainya. 
b. Creation of System Matrix, pembuatan matriks sistem untuk menghitung aliran massa. Jumlah pipa sama dengan jumlah persamaan yang dibentuk dari model sistem sehingga matriks akan berbentuk persegi. Laju aliran massa dihitung dari neraca massa dan energi setiap komponen. Neraca massa dan energi dituliskan dalam matriks.

c. Caculating Composistions, jenis medium kerja dan komposisi gas ditentukan.

d. Difference in Compositions, menentukan jumlah pipa yang tidak memenuhi break-off criterion yang dinyatakan oleh pertidaksamaan ;

$\left|\mathrm{C}_{\mathrm{j}}(\mathrm{i})-\mathrm{C}_{\mathrm{j}}(\mathrm{i}-1)\right|<\epsilon$

e. Calculating $\mathrm{p}, \mathrm{T}, \mathrm{h}$, perhitungan tekanan, temperatur, dan entalpi menggunakan neraca energi masing-masing komponen.

f. Solving System Matrix, penyelesaian matriks sistem dengan metode Eliminasi Gauss yang akan menghasilkan laju aliran massa sistem.

g. Difference in Mass Flows, perhitungan selisih laju aliran massa dari break off criterion yaitu ;

$$
\left|\frac{\dot{m}(i)-\dot{m}(i-1]}{\dot{m}(i)}\right|<\in \text { atau }|\dot{\mathrm{m}}(\mathrm{i})-\dot{\mathrm{m}}(\mathrm{i}-1)|<0,001
$$

h. Break-off Criterion Compositions/Mass Flow, terjadi jika setiap pipa memenuhi baik kriteria komposisi dan laju aliran massa. Jika sudah memenuhi maka laju aliran massa merupakan solusi matriks, sedangkan jika tidak maka perhitungan kembali pada langkah ke tiga.

i. Calculating Compositions, komposisi yang memenuhi pada langkah ke delapan merupakan komposisi akhir yang merupakan solusi matriks.

j. Calculating $\mathrm{p}, \mathrm{T}, \mathrm{h}$ nilai tekanan, temperatur, dan entalpi yang belum diketahui dihitung kembali sesuai dengan laju aliran massa dan komposisi yang telah didapatkan.

k. Output, neraca energi pada setiap komponen didapatkan dari persamaan :

$$
\sum_{j=1}^{n} \bar{m}_{\text {in }}(\mathrm{j}) \mathrm{h}_{\text {in }}(\mathrm{j})-\sum_{i=1}^{n} \bar{m}_{\text {out }}(\mathrm{i}) \mathrm{h}_{\text {out }}(\mathrm{i})=\mathrm{Q}-\mathrm{W}
$$

1. Exergy Analysis, perhitungan nilai eksergi baik sistem secara keseluruhan maupun masing-masing komponen.

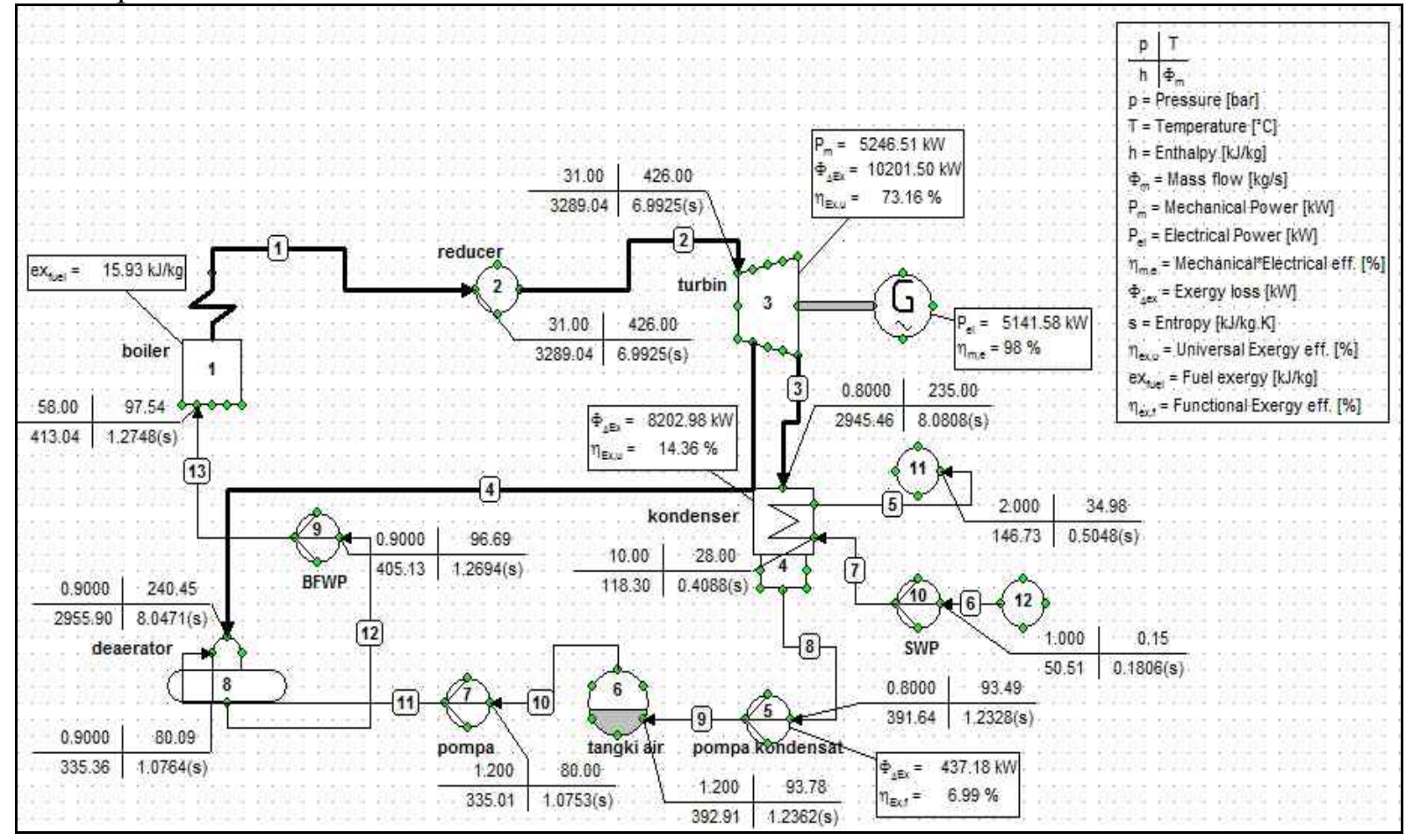

Gambar 5. System Model Thermal Power Plant Using Cycle Tempo 5 
Dalam analisis eksergi dari proses dan sistem termodinamika melibatkan perhitungan eksergi yang diserap (absorb) oleh sistem atau komponen, exergy yang diterima (deliver) pada proses tersebut. Losses ini dapat disebabkan oleh drainage dan degradation energi. Besarnya jumlah losses dapat dihitung dengan menggunakan efisiensi exergy dari proses, komponen, atau sistem. Efisiensi exergy juga dapat menunjukkan kualitas dari konversi energi pada sistem pembangkit.

Untuk menghitung nilai eksergi, pertama harus ditentukan dahulu referensi atau kondisi lingkungan ketika perhitungan dilakukan. Misalnya suhu dan tekanan lingkungan To dan Po.

Proses perpindahan eksergi selalu menyertakan kontribusi lingkungan sistem dimana proses tersebut berlangsung, sehingga laju perpindahan eksergi dapat ditulis dengan persamaan :

$$
E x=\dot{m}\left(h_{\text {out }}-h_{\text {in }}\right)-T_{o}\left(S_{\text {out }}-S_{\text {in }}\right)
$$

Dimana :

$\dot{\mathrm{m}}=$ Laju aliran massa uap $(\mathrm{kg} / \mathrm{s})$

$\mathrm{h}_{\text {out }}=$ Entalpi zat yang keluar dari komponen $(\mathrm{kJ} / \mathrm{kg})$

$\mathrm{h}_{\text {in }}=$ Entalpi zat yang masuk dari komponen $(\mathrm{kJ} / \mathrm{kg})$

$\mathrm{T}_{\mathrm{o}}=$ Suhu lingkungan yang berada pada atmosfir standar sebesar $303,15^{\circ} \mathrm{K}$

$\mathrm{S}_{\text {out }}=$ Entropi zat yang keluar dari komponen $\left(\mathrm{kJ} / \mathrm{kg}{ }^{\circ} \mathrm{K}\right)$

$\mathrm{S}_{\text {in }}=$ Entropi zat yang masuk dari komponen $\left(\mathrm{kJ} / \mathrm{kg}{ }^{\circ} \mathrm{K}\right)$

Persamaan untuk menghitung nilai eksergi yang hilang, digunakan persamaan berikut :

$$
\mathrm{Ex}_{\text {Losses }}=\mathrm{Ex}_{\mathrm{in}}-\mathrm{Ex}_{\text {out }}
$$

Dimana :

$$
\begin{array}{ll}
\mathrm{Ex}_{\text {losses }} & =\text { Kerugian eksergi }(\mathrm{kW}) \\
\mathrm{Ex}_{\text {in }} & =\text { Eksergi yang diserap }(\mathrm{kW}) \\
\mathrm{Ex}_{\text {out }} & =\text { Eksergi yang diterima }(\mathrm{kW})
\end{array}
$$

Efisiensi eksergi pada setiap subsistem dapat dituliskan seperti pada persamaan (2.3)

$$
\eta=\frac{\mathrm{Ex} \text { losses }}{\mathbb{E x} \text { in }} x 100
$$

Dimana :

$\mathrm{Ex}_{\text {losses }}=$ Kerugian eksergi subsistem $(\mathrm{kW})$

$\mathrm{Ex}_{\mathrm{in}} \quad=$ Eksergi yang masuk ke dalam masing-masing subsistem $(\mathrm{kW})$

Persamaan menghitung biaya rugi-rugi eksergi, acuan yang digunakan untuk biaya adalah tarif dasar listrik Indonesia per bulan Juni 2015 sebesar Rp. 1.524 per kWh. Perhitungan termoekonomi didapatkan dengan persamaan :

$$
\mathrm{C}=\frac{\operatorname{ExxRp} / \mathrm{kWh} \times 24}{1000}
$$

Dimana :

$\mathrm{C}=$ Rugi-rugi biaya (Rupiah per hari)

$\mathrm{Ex}=$ Eksergi $(\mathrm{kW})$

Berdasarkan analisis eksergi sistem PLTU dan simulasi menggunakan cycle tempo 5 yang telah dilakukan, maka hasil persentase efisiensi eksergi tertinggi terdapat pada komponen turbin $49,02 \%$ dan simulasi $51,43 \%$, kemudian kondenser $15,20 \%$ dan simulasi $14,36 \%$, pompa dan boiler $0 \%$. Untuk lebih jelasnya, dapat dilihat pada Tabel 4.2 di bawah ini.

Selanjutnya untuk hasil eksergi losses pada komponen sistem PLTU tertinggi pada komponen turbin $9919,7 \mathrm{~kW}$ dan simulasi 10201,50 kW, kemudian kondenser 8218,996 kW dan simulasi 8202,98 
$\mathrm{kW}$, pompa 15,738 kW dan simulasi 437,18 kW serta boiler $0 \mathrm{~kW}$. Untuk lebih jelasnya, dapat dilihat pada Tabel 4.3 di bawah ini.

Tabel 2. Efisiensi eksergi komponen

\begin{tabular}{|c|c|c|}
\hline Nomor komponen & Komponen & Efisiensi eksergi (\%) \\
\hline 3 & Turbin & 51,43 \\
\hline 4 & Kondenser & 14,36 \\
\hline 5 & Pompa & 0,00 \\
\hline 1 & Boiler & 0,00 \\
\hline
\end{tabular}

Tabel 3. Eksergi losses komponen

\begin{tabular}{|c|c|c|}
\hline Nomor komponen & Komponen & Eksergi losses (kW) \\
\hline 3 & Turbin & 10201,50 \\
\hline 4 & Kondenser & 8202,98 \\
\hline 5 & Pompa & 437,18 \\
\hline 1 & Boiler & 0,00 \\
\hline
\end{tabular}

\section{KESIMPULAN}

Berdasarkan simulasi, analisis dan pembahasan yang telah dilakukan, maka kesimpulan yang dapat diperoleh dari penelitian ini adalah sebagai berikut :

a. Nilai eksergi yang dianalisis pada sistem PLTU yang dimodelkan terdiri dari komponen turbin sebesar 10201,50 kW, kondenser sebesar 8202,98 kW, pompa sebesar 437,18 kW dan boiler sebesar $0 \mathrm{~kW}$. Boiler tidak dimasukkan dalam analisis karena pada input komponen tersebut tidak terdapat laju aliran massa serta pada boiler terjadi steady state dimana keadaan proses sama dengan keadaan lingkungan disekitarnya sehingga tidak ada selisih eksergi yang dapat dimanfaatkan.

b. Nilai eksergi yang hilang (exergy losses) tertinggi sesuai permodelan terdapat pada komponen turbin yaitu sebesar $10201,50 \mathrm{~kW}$. Hal ini disebabkan karena adanya perubahan fasa uap menjadi fasa cair yang terdapat pada sebelum komponen dan setelah meninggalkan komponen turbin. Sedangkan nilai eksergi losses terendah terdapat pada komponen pompa yaitu sebesar $437,18 \mathrm{~kW}$.

c. Semakin tinggi nilai efisiensi suatu komponen, menyatakan bahwa performansinya semakin baik. Nilai efisiensi eksergi tertinggi sebesar 51,43\% terdapat pada komponen turbin. Sedangkan nilai efisiensi eksergi terendah terdapat pada komponen pompa dan boiler sebesar $0 \%$.

d. Biaya rugi-rugi eksergi yang digunakan pada turbin karena nilai eksergi terbesar dan beracuan pada tarif dasar listrik Indonesia per bulan Juli 2015 sebesar Rp. 1.524 per kWh. Sehingga pada $\Delta$ Exlosses $=10201.50$ adalah diperoleh biaya rugi-rugi eksergi sebesar Rp. 373130,1 per hari.

\section{DAFTAR PUSTAKA}

[1] NINGSIH, P. S. (2013). ANALISIS EKSERGI PADA PEMBANGKIT LISTRIK TENAGA UAP (Doctoral dissertation, Universitas Gadjah Mada).

[2] Karyadi, A., \& Rangkuti, C. (2016). Analisa Energi Dan Eksergi Pembangkit Listrik Tenaga Uap Banten 3 Lontar. In PROSIDING SEMINAR NASIONAL CENDEKIAWAN (pp. 3-1).

[3] Priambodo, D., Dewita, E., \& Irianto, I. D. (2015). Analisis energi dan eksergi pada sistem HTR10 siklus turbin uap. Jurnal Pengembangan Energi Nuklir, 17(1), 33-43. 
[4] Sundari, P., Rudiyanto, B., \& Hariyono, B. (2015). Kajian Eksergi Pembangkit Listrik Tenaga Gas (Studi Kasus di PT. Indonesia Power Up Perak-Grati). Jurnal Sains dan Teknologi Indonesia, 17(3).

[5] Samosir, W. L., \& Martin, A. (2015). Analisis Exergy pada Combustion Chamber Pembangkit Listrik Tenaga Gas Uap (PLTGU) Teluk Lembu 30 MW. Jurnal Online Mahasiswa Fakultas Teknik Universitas Riau, 2(2), 1-7.

[6] Aziz, A. (2011). Analisa Eksergi PLTP Kamojang 68 Kapasitas 3 MW. Jurnal Rekayasa Lingkungan Badan Pengkajian dan Penerapan Teknologi, 7(2), 115-125.

[7] Hetharia, M. \& Lewerissa, Y. J. (2018). Analisis Energi Pada Perencanaan Pembangkit Listrik Tenaga Uap (Pltu) Dengan Cycle Tempo. Jurnal Voering, 3(1), 23-30. 